\title{
Incidence and risk factors of urinary incontinence in women visiting Family Health Centers
}

Meral Kılıç

\begin{abstract}
Background: The objective of this study is to determine the incidence and the risk factors of the urinary incontinence in women visiting the Health Family Center.

Methods: 430 women, who visited three Family Health Centers in the city center of Erzurum for any reason between 25 November and 20 January 2016, were included in this study without any sampling. The data were collected by using the face-to-face interview method. Percentage distribution, Chi square test, and logistic regression analysis were used in order to analyze the data.

Results: It was determined that $37.2 \%$ of these women had urinary incontinence, but only $29.3 \%$ of them visited a physician because of this complaint. Among a total of 160 women with urinary incontinence findings, stress type incontinence was observed at the highest rate (33.7\%), which was followed by mixed type (31.8\%), urge type (20.6\%) and other types (overflow, continuous urinary incontinence) (13.7\%). It was found that urinary incontinence had a significant correlation with the number of children, genital prolapse, duration of delivery longer than $24 \mathrm{~h}$, diabetes and urogenital infection, but not with the age at the first and last childbirth, presence of the episiotomy, birth weight over $4 \mathrm{~kg}$, and smoking.

Conclusions: It was determined that one-third of the women had urinary incontinence and certain medical and obstetric conditions were affecting the development of urinary incontinence. It is thought that it is important for the healthcare personnel to take the progression of the urinary incontinence under control by preventing the risk factors and to encourage the patients to seek treatment with the help of the proper information indicating that urinary incontinence is a treatable and preventable condition.
\end{abstract}

Keywords: Urinary incontinence, Prevalence, Risk factors

\section{Background}

Urinary incontinence (UI) is a storage symptom and defined as the complaint of any involuntary loss of urine (Abrams et al. 2010). Worldwide over 200 million people have an incontinence problem, which is encountered often in healthy persons, especially in women. Its prevalence is between 15 and 50 \% (Basak et al. 2013; Norton and Brubaker 2006; Nygaard et al. 1994). Although urinary incontinence is not a life-threatening problem,

*Correspondence: m_kavak25@hotmail.com; meral.kilic@atauni.edu.tr Department of Midwifery, Faculty of Health Science, Ataturk University, Erzurum, Turkey it may cause emotional disorders like depression due to continuous wetness and irritation. In the literature, it is shown that women with incontinence symptoms are more prone to depression, have higher anxiety levels, and feel more humiliated compared to women without incontinence symptoms (Berglund et al. 1994; Valvanne et al. 1996; Williams 2004). Due to the fear of incontinence, routine daily life activities might be stressful and embarrassing. It is determined that the incontinence might affect negatively traveling, shopping, playing with children, exercising and sexual activity and the quality of life might impair (Williams et al. 2001). 
Urinary incontinence may develop as a result of aging and childbirth. Although it is common among elderly people, it should not be interpreted as a geriatric disorder since it is not rare among middle-aged and young people (Ostergard and Bent 1996). In a study, the prevalence of UI was $12.8 \%$ in young people, $36.1 \%$ in middle-aged people, and $35 \%$ in old people (Chiarelli et al. 1999). In another study, it was shown that UI was more common in young women rather than 60 year-old people (Nygaard et al. 1994). One study reported that the highest rate of stress incontinence was encountered in women aged between 25 and 49 years (Hannestad et al. 2000).

In women, the most significant risk factors associated with UI are pregnancy, childbirth, age, body mass index, and previous hysterectomy. Gender, previous pelvic surgery, obesity, chronic cough, depression, type of childbirth, smoking, genetics, menopause, hormone replacement therapy in the post-menopausal period are the other risk factors (Doughty 2012; Melville et al. 2005; Ortiz 2004). The most apparent risk factors among women with UI have been reported to be vaginal delivery, macrosomia, high number of pregnancies, interventional births, and vaginal episiotomy (Kocaöz and Eroglu 2002; Kasikçi et al. 2015).

In Turkey, most of the women are multiparous; therefore, they have urinary incontinence as a result of the weakened pelvic muscles, which affect them seriously in medical, physical, social, psychological and economic aspects and impair their quality of life (Bates et al. 1979; Taşkın 2007). The context of the concept of quality of life is closely related with nursing and midwifery interventions. Therefore, the activities of nurses and midwives should focus on behaviors and reactions, which have a positive effect on quality of life (Kızılkaya 2002; Şirin and Kavlak 2008). Within this scope, prevention of the development of the incontinence and having an active role in the treatment of women with this disorder are one of the basic responsibilities of the nurses and midwives. In order to prevent urinary incontinence, risk factors should be well known (Bates et al. 1979). This study was conducted in order to determine the incidence and risk factors of the urinary incontinence among women applying to the Family Health Center.

\section{Participants and methods \\ Participants}

This study was conducted in Filiz Dolunay, Yenişehir, and Yildızkent Family Health Centers in the city center of Erzurum between 25 November 2015 and 20 January 2016. The sample group consisted of 430 women visiting these three Family Health Centers in the city-center of Erzurum for any reason. All women were included in the study without any sampling. The inclusion criteria were as follows; being over 20 years of age, presence of previous childbirth, willingness to participate, and lack of any acute, mental, and auditorial disorder.

\section{Data collection}

The "Information Form" prepared by the researchers was used to record the data. The Personal Information Form was prepared according to the samples in the literature (AnChiu et al. 2008; Karaçam and Eroğlu 2003; Milsom et al. 1993; Ortiz 2004). There was a total of 22 questions in this Personal Information Form regarding age, educational background, socio-demographic, medical and obstetric characteristics, UI experience, UI frequency, and urine volume. The patients who answered any of the data marked with $\left(^{*}\right)$ in Table 2 as "yes" were accepted to have "urinary incontinence findings" in accordance with the literature (Table 2). In the section where we aimed to determine the severity level of UI, the patients were asked questions regarding frequency of urinary incontinence and whether or not they use pad. Those who had one or more incidence of incontinence and/or those who did not use pad were classified as "mild UI". Those who had incontinence problem almost every day and had to use continuously pad were accepted as "severe UI". The cases between these two categories, the cases who had incontinence problem more than two per a week though not every day and for whom pad usage was not consistent, were called as "moderate UI" (Table 2).

Those, having history of any chronic disease (diabetes mellitus, pelvic organ prolapse (POP), repeated urinary tract infection etc.,) diagnosed by the physician previously, were accepted to have "urinary incontinence findings".

Those having urinary tract infections which progressed with three and more number of symptomatic attacks within the last 1 year and were diagnosed by the physician were accepted to have "repeated urinary tract infection".

The data were collected by using the face-to-face interview method from the women who visited the mentioned Family Health Centers for any reason or were reached at home as from November 2015. Each interview lasted for 10-15 min.

\section{Statistical analysis}

Encoding and assessment of the data were performed by using SPSS v20.0 software (Statistical Package for Social Science). Number and percentage distributions were used for descriptive statistics and the related evaluations were performed by using Chi square test and logistic regression analysis. 


\section{Drawbacks and limitations of the study}

The memory impairment of the elderly people may raise difficulties concerning the retrospective information especially regarding childbirth. However, the planned study was important for understanding the etiology and risk factors of UI.

\section{Ethical issues}

In order to conduct this study, ethical approval of Atatürk University Institutional of Health Sciences Review Board according to the Declaration of Helsinki (IRB No. CMUH-34/21.12.2015) was received. All participants gave informed written consent prior to inclusion in the study. As the questions had to be answered voluntarily, we informed that they were free in participating in the study and we assured their willingness and voluntariness. After the participants were informed and their questions were answered about the study, their verbal and written consent were obtained before starting the study. They were also informed that they could withdraw from the study anytime.

\section{Results}

$36.3 \%$ of the women were aged between 30 and 39 years. $48.4 \%$ of them were primary school graduates, $97.9 \%$ were married, and $72.2 \%$ did not have a job (Table 1 ).

$12.5 \%$ of the women participating in the study were observed to have urinary incontinence during coughing, sneezing or daily activities (stress type), $11.8 \%$ during coughing, sneezing and when in need of urinating (mixed type), $7.67 \%$ when in need of urinating (urge type), and $5.11 \%$ in cases of other types (reflex type UI developing due to congenital or subsequent anatomic abnormalities such as overflow incontinence, urethrovaginal fistulas, ectopic ureter) (Table 2).

The patients who answered any of the data marked with (") in Table 2 as "yes" were accepted to have "urinary incontinence findings" in accordance with the literature. Accordingly, 160 (37.2\%) of a total of 430 patients participating in the study were determined to have any urinary incontinence (Table 2).

It was determined that only $29.3 \%$ of these patients applied a healthcare organization due to urinary incontinence and UI findings were experienced between 1 and 12 months at higher rate (Table 3). $33.7 \%$ of the women were observed to have urinary incontinence during coughing, sneezing or daily activities (stress type), $20.6 \%$ during coughing, sneezing and when in need of urinating (mixed type), $31.8 \%$ when in need of urinating (urge type), and $13.7 \%$ in cases of other types (reflex type UI developing due to congenital or subsequent anatomic abnormalities such as overflow incontinence, urethrovaginal fistulas, ectopic ureter) (Table 3). In the studies
Table 1 Maternal characteristics $(n=430)$

\begin{tabular}{lrr}
\hline & Number & $\%$ \\
\hline Maternal age & 87 & \\
$20-29$ & 156 & 20.2 \\
$30-39$ & 120 & 36.3 \\
$40-49$ & 67 & 27.9 \\
50 and above & & 15.6 \\
Educational status & 44 & \\
Illiterate & 208 & 10.2 \\
Primary school graduate & 178 & 48.4 \\
Secondary school graduate & & 41.4 \\
Married & 421 & \\
Yes & 9 & 2.1 \\
No & & 27.8 \\
Employment status & 119 & 72.2 \\
Yes & 311 & \\
No & & \\
\hline
\end{tabular}

determining severity of UI by evaluating frequency of UI and the usage of pad, the results obtained for all the sample group were determined as $77.5,16.3$, and $6.2 \%$ for mild, moderate and severe UI (Table 3).

$42.2 \%$ of them gave their first birth between the ages of $20-25$ years, age of $34.5 \%$ at the last childbirth was between the ages of 30-34 years, and $52.9 \%$ had $1-2$ children. $30 \%$ had a duration of delivery longer than $24 \mathrm{~h}, 43.2 \%$ had an episiotomy, and $34.7 \%$ gave birth to a child with a birth weight over $4 \mathrm{~kg}$. It was found determined that $15.3 \%$ of the women had genital prolapse, $21.9 \%$ had diabetes, $8.8 \%$ had a urogenital infection, and $34 \%$ were smokers (Table 4 ).

It was determined that $15.3 \%$ of the women had POP, $21.9 \%$ had diabetics, $8.8 \%$ had urogenital infection, and $34 \%$ were smokers (Table 5 ).

According to the correlation of UI with medical and obstetric characteristics and to the logistic regression analysis of the risk factors; number of children, genital prolapse, duration of delivery longer $24 \mathrm{~h}$, diabetes, and urogenital infection had a significant correlation with UI, but not with age at the first and last childbirth, presence of episiotomy, birth weight over $4 \mathrm{~kg}$, and smoking. (Table 6).

In the present study, according to the logistic regression analysis regarding the relation of the urinary incontinence and medical and obstetric characteristics; it was determined that number of children, long duration of delivery, and POP were risk factors for UI in women. It was also found that the age at the first and last childbirth, presence of episiotomy, birth weight over $4 \mathrm{~kg}$, diabetes, urogenital infection, and smoking were not risk factors for UI (Table 6). 
Table 2 Characteristics related to urinary incontinence findings $(n=430)$

\begin{tabular}{|c|c|c|}
\hline & Number & $\%$ \\
\hline \multicolumn{3}{|l|}{ Characteristics } \\
\hline Urinary incontinence during coughing, sneezing or daily activities (Stress type)* & 54 & 12.5 \\
\hline Urinary incontinence during coughing, sneezing and when in need of urinating (mixed type)* & 51 & 11.8 \\
\hline Urinary incontinence when in need of urinating (urge type)* & 33 & 7.67 \\
\hline Any case of urinary incontinence & 160 & 37.2 \\
\hline \multicolumn{3}{|l|}{ Severity of urinary incontinence } \\
\hline Those who had once or less incidences of incontinence per week or/and did not use pad (mild UI) & 124 & 28.8 \\
\hline $\begin{array}{l}\text { The cases who had incontinence problem more than two per a week though not every day and for whom pad usage was not } \\
\text { consistent, (moderate UI) }\end{array}$ & 26 & 6.04 \\
\hline Those who had incontinence problem almost every day and had to use pad (severe UI) & 10 & 2.32 \\
\hline
\end{tabular}

*: (*) patients who answered any of the data marked with $\left(^{*}\right)$ as "Yes" were accepted to have "urinary incontinence findings" in accordance with the literature

Table 3 The Distribution of the patients with urinary incontinence findings based on urinary incontinence types

\begin{tabular}{|c|c|c|}
\hline & Number & $\%$ \\
\hline \multicolumn{3}{|l|}{ Types $(n=160)$} \\
\hline Stress type urinary incontinence & 54 & 33.7 \\
\hline Urge type urinary incontinence & 33 & 20.6 \\
\hline Mixed type urinary incontinence & 51 & 31.8 \\
\hline Others & 22 & 13.7 \\
\hline \multicolumn{3}{|l|}{ Urinary incontinence $(n=430)$} \\
\hline Yes & 160 & 37.2 \\
\hline No & 270 & 62.8 \\
\hline \multicolumn{3}{|c|}{$\begin{array}{l}\text { Applying to a health organization due to urinary incon- } \\
\text { tinence }(n=160)\end{array}$} \\
\hline Yes & 47 & 29.3 \\
\hline No & 113 & 70.2 \\
\hline \multicolumn{3}{|c|}{$\begin{array}{l}\text { Period of experiencing involuntary leakage of urine } \\
(n=160)\end{array}$} \\
\hline $1-12$ months & 105 & 65.6 \\
\hline 13-48 months (4 years) & 26 & 16.2 \\
\hline 49-96 months (8 years) & 9 & 5.6 \\
\hline 97 months & 20 & 12.6 \\
\hline \multicolumn{3}{|l|}{ Severity of urinary incontinence $(n=160)$} \\
\hline Those with mild urinary incontinence & 124 & 77.5 \\
\hline Those with moderate urinary incontinence & 26 & 16.3 \\
\hline Those with severe urinary incontinence & 10 & 6.2 \\
\hline
\end{tabular}

\section{Discussion}

Urinary incontinence is an important medical and social public-health problem for people with incontinence, his/ her family and due to its cost to the healthcare system (Shakhatreh 2005). In Turkey, the prevalence of UI vary between 15 and $50 \%$ (Basak et al. 2013; Bilgili et al. 2008). In their study Hunskaar et al. (2003) determined that the prevalence of UI among women in European countries was $23 \%$ in Spain, 41 \% in Germany, $42 \%$ in the UK, and
$44 \%$ in France. In the present study, it was found that $37.2 \%$ of the women had urinary incontinence. Similar to results of the present study, Kök et al. (2006) reported in their study that $37.11 \%$ of the women visiting the gynecology outpatient clinic had urinary incontinence. In the study conducted by Ateşkan et al. (2000), the incidence of UI was $39.7 \%$ in the sample group. The difference in its prevalence might be a result of different ages of patients included in the study, the different diagnostic criteria used for UI, different survey forms, and different data collection methods (Basak et al. 2013).

It was found that although one-third of the women had urine leakage problem, $70.7 \%$ did not visit a physician for this complaint. The ratio of the patients visiting a physician for urinary incontinence was $14 \%$ in the study of Hägglund et al. (2001), 38 \% in the study of Kinchen et al. (2003), and $27 \%$ in the study of Yu et al. (2003). In the literature, the main reasons reported for not visiting a physician were the hope for recovery of symptoms, shyness and hesitation to talk with a physician about this problem, fear of operation and the assumption that it is a natural consequence of childbirth and aging (Kinchen et al. 2003; Ortiz 2004). The severity of the incontinence is also affecting the rate of visiting a physician. Another evidence directly demonstrates that perceived UI severity is a predictor of help-seeking behavior among incontinent women (Koch 2006). Another study revealed that lower subjective UI severity or lower perceived UI severity contributed to longer delay to treatment (Wu et al. 2015). In the present study, it was determined that $77.5 \%$ of the women had mild urinary incontinence, $16.3 \%$ moderate urinary incontinence, and $6.2 \%$ severe urinary incontinence. Therefore, the reason for the low rate of visiting a physician may be the fact that majority of the women had mild UI. This may delay the diagnosis and treatment of the disorder (Kinchen et al. 2003). For this reason, the awareness about the importance of the early diagnosis 
Table 4 The distribution of obstetric characteristics of women $(n=430)$

\begin{tabular}{lcc}
\hline & Number & $\%$ \\
\hline Age at the first childbirth & 178 & \\
20 and below & 182 & 41.5 \\
$20-25$ & 70 & 42.2 \\
25 and above & & 16.3 \\
Age at the last childbirth & 62 & \\
25 and below & 118 & 14.6 \\
$25-29$ & 152 & 27.8 \\
$30-34$ & 98 & 34.5 \\
35 and above & & 23.1 \\
Number of children & 228 & \\
$1-2$ & 142 & 32.9 \\
$3-4$ & 60 & 14.0 \\
5 and above & & \\
Duration of delivery longer $24 \mathrm{~h}$ & 129 & 30.1 \\
Yes & 301 & 69.9 \\
No & & \\
Presence of episiotomy & 186 & 34.7 \\
Yes & 244 & 56.8 \\
No & & \\
Birth weight over 4 kg & 149 & \\
Yes & 281 & \\
No & & \\
\hline
\end{tabular}

Table 5 The distribution of urinary incontinence-related characteristics of the women

\begin{tabular}{llr}
\hline & Number & $\%$ \\
\hline Genital prolapse & $\mathrm{n}=430$ & \\
Yes & 66 & 15.3 \\
No & 364 & 84.7 \\
Diabetes & $\mathrm{N}=430$ & \\
Yes & 94 & 21.9 \\
No & 336 & 78.1 \\
Urogenital infection & $\mathrm{n}=430$ & \\
Yes & 38 & 8.8 \\
No & 391 & 91.2 \\
Smoking & $\mathrm{n}=430$ & \\
Yes & 146 & 34.0 \\
No & 284 & 66.0 \\
\hline
\end{tabular}

and treatment in UI should be increased. People, who have incontinence but maintain apparently a life without much disturbed by this condition, may be encouraged to seek health advice by informing them that this disorder is treatable and preventable (Kizılkaya 2002).

SUI was the predominant subtype among women in the present study. SUI was the commonest subtype of UI in many studies conducted on females (Çiftçi and Günay 2011; Ghafouri et al. 2014; Altaweel and Alharbi 2012; Al-Badr et al. 2012). However, other studies reported mixed UI as being more common than stress UI (El-Azab et al. 2007; Rizk et al. 2001).

Childbearing may cause urinary incontinence in women. The present study revealed a significant correlation between the number of children and UI. In a previous study, it was reported that UI was $5.5 \%$ among nulliparous women, $10.6 \%$ among primiparous women, and $16.4 \%$ among women with more than 3 deliveries (Milsom et al. 1993). In another study, it was showed that the prevalence of both stress and urge incontinence was lower among nulliparous women and higher among women with 5-6 deliveries (Shakhatreh 2005). Kocaöz and Eroglu (2002) found a significant correlation between stress incontinence and several risk factors such as the number of pregnancies, miscarriages, number of births, number of miscarriages, birth location, and complaint of UI during pregnancy. This may be associated with the impairment in the pelvic muscle nerves during birth, the development of atrophy in muscles, and the development of prolapse over time (Kasikçi et al. 2015).

In the present study, it was found that there was a significant correlation between the UI and delivery lasting longer than $24 \mathrm{~h}$ and the logistic regression analysis revealed that delivery lasting longer than $24 \mathrm{~h}$ was a risk factor for UI. However in a previous study, it was reported that delivery lasting longer than $24 \mathrm{~h}$ did not have a prominent effect on UI (Thom and Brown 1998). Another study revealed that delivery lasting longer than $24 \mathrm{~h}$ increased the development rate of moderate or severe urinary incontinence 1.3 times (Rortveit et al. 2003). It was suggested that the pudendal nerve damage after long and difficult delivery and pubococcygeus muscle weakness were possibly the reason for urine leakage. It is thought that the mechanism of the nerve damage during the delivery may be both the stretching of the pelvic floor and direct pressure of the fetal head on the nerve along the pelvic side walls (Thom and Brown 1998).

Another factor affecting the development of UI is the childbirth with a birth weight over $4 \mathrm{~kg}$. Its probable consequence is the damage to the pudendal nerve, connective tissue and pelvic floor muscles (Højberg et al. 1999). In the present study, it was determined that history of a big baby was not a risk factor for UI. Several studies showed that the childbearing with a birth weight over $4 \mathrm{~kg}$ did not cause the development of UI (Connolly et al. 2007; Viktrup et al. 1992). On the other hand, in some studies, it was found that childbearing with a birth weight over $4 \mathrm{~kg}$ affected UI (Højberg et al. 1999; Oliveira et al. 2010). 
Table 6 Logistic regression analysis regarding the correlation of the urinary incontinence and medical and obstetric characteristics

\begin{tabular}{|c|c|c|c|c|}
\hline & \multicolumn{2}{|c|}{ Urinary incontinence (UI) } & \multirow[t]{2}{*}{ Test value and $p$} & \multirow[t]{2}{*}{ OR } \\
\hline & With UI number & Without UI number (\%) & & \\
\hline \multicolumn{5}{|c|}{ Age at the first childbirth } \\
\hline 20 and below & $71(39.9)$ & $107(60.1)$ & ${ }_{x}^{2}=4.766$ & $1.036(752-1.426)$ \\
\hline $20-25$ & $68(38.2)$ & $110(61.8)$ & $p=.190$ & $p=.830$ \\
\hline 25 and above & $21(28.3)$ & $53(71.7)$ & & \\
\hline \multicolumn{5}{|c|}{ Age at the last childbirth } \\
\hline 25 and below & $23(37.1)$ & $39(62.9)$ & $x_{x}^{2}=4.093$ & $1.144(.886-1.512)$ \\
\hline $25-29$ & $35(29.7)$ & $83(70.3)$ & $p=.252$ & $p=.342$ \\
\hline $30-34$ & $58(39.5)$ & $89(60.5)$ & & \\
\hline 35 and above & $44(42.7)$ & $59(57.2)$ & & \\
\hline \multicolumn{5}{|c|}{ Number of children } \\
\hline $1-2$ & $66(29.1)$ & $162(70.9)$ & $\frac{2}{x}=.196$ & $.619(.424-.904)$ \\
\hline $3-4$ & $61(43.0)$ & $81(57.0)$ & $p=.000$ & $p=.013$ \\
\hline 5 and above & $33(55.0)$ & $27(45.0)$ & & \\
\hline \multicolumn{5}{|c|}{ Duration of delivery longer $24 \mathrm{~h}$} \\
\hline Yes & $58(45.0)$ & $71(55.0)$ & $\frac{2}{x}=4.826$ & $1.694(1.067-2.692)$ \\
\hline No & $102(33.8)$ & $200(66.2)$ & $p=.028$ & $p=.026$ \\
\hline \multicolumn{5}{|c|}{ Presence of episiotomy } \\
\hline Yes & $73(39.2)$ & $113(60.8)$ & $\frac{2}{x}=.524$ & $995(911-1.087)$ \\
\hline No & $87(35.7)$ & $157(64.3)$ & $p=.769$ & $p=909$ \\
\hline \multicolumn{5}{|c|}{ Birth weight over $4 \mathrm{~kg}$} \\
\hline Yes & $51(34.2)$ & $98(65.8)$ & $\frac{2}{x}=.919$ & $655(412-1.040)$ \\
\hline No & $109(38.9)$ & $172(34.2)$ & $p=.338$ & $p=.073$ \\
\hline \multicolumn{5}{|l|}{ Genital prolapse } \\
\hline Yes & $42(63.6)$ & $24(36.4)$ & $\frac{2}{x}=23.306$ & $2.878(1.597-5.185)$ \\
\hline No & $118(32.4)$ & $246(67.6)$ & $p=.000$ & $p=.000$ \\
\hline \multicolumn{5}{|l|}{ Diabetes } \\
\hline Yes & $34(36.2)$ & $60(63.8)$ & $\frac{2}{x}=16.548$ & $984(792-1.221)$ \\
\hline No & $126(37.6)$ & $209(62.4)$ & $p=.000$ & $p=.881$ \\
\hline \multicolumn{5}{|c|}{ Urogenital infection } \\
\hline Yes & $23(60.5)$ & 15 (39.5) & $\frac{2}{x}=9.700$ & $1.899(895-4.030)$ \\
\hline No & $137(34.9)$ & $255(65.1)$ & $p=.002$ & $p=.095$ \\
\hline \multicolumn{5}{|l|}{ Smoking } \\
\hline Yes & $52(35.6)$ & $94(64.4)$ & $\frac{2}{x}=.240$ & 1.061 (672-1.675) \\
\hline No & $108(38.0)$ & $176(62.0)$ & $p=.624$ & $p=801$ \\
\hline
\end{tabular}

Significant values are in italics

In the present study, it was found that episiotomy did not affect the development of UI. Bilgili et al. (2008) found no significant correlation between vaginal episiotomy, age at first childbirth, and UI. Other studies also showed that vaginal episiotomy had no effect on UI (Karaçam and Eroglu 2003; Sartore et al. 2004). In a previous study, it was found that regarding the urinary incontinence in the 3rd month after the delivery, the score/ status of urinary incontinence was significantly higher among women with episiotomy compared to women without episiotomy (Chang et al. 2011). According to the literature, it was concluded that episiotomy was effective in the prevention of the anterior perineal laceration, but not in the prevention of the perineal damage, and especially in the prevention of urinary and anal incontinence and pelvic floor relaxation (Hartmann et al. 2005).

Genital prolapse and urinary incontinence might be seen concomitantly in the same patient. They might cause cystocele and micturition difficulties (Kizllkaya 2002). The present study revealed a significant correlation between UI and prolapses. In a previous study, it was determined that among women aged over 65 years, the 
risk of urinary incontinence was higher in women with a genital prolapse compared to women without a genital prolapse (Bilgili et al. 2008). It is thought that the damage to the nerves and muscles in the pelvic floor is the main causative factor regarding the development of the POP. Therefore, if the genital prolapse is developed, urinary and anal incontinence might develop in the same patient (Meschia et al. 2002).

The present study revealed a correlation between urinary infection and UI. In studies with similar results, it was shown that there was a significant correlation between the history of frequent urinary tract infections and the incidence of urinary incontinence (Hägglund et al. 1999; Isikli et al. 2011). The reason for this might be the increase in detrusor muscle contractions and sphincter pressure depending on the infection (Basak et al. 2013).

Another factor affecting urinary incontinence is diabetes mellitus. In the present study, it was determined that diabetes affected the development of UI. Similar to results of the present study, some other studies revealed a significant correlation between diabetes and UI (Brown et al. 1996; Nakayama et al. 1997; Shakhatreh 2005). On the other hand, three other studies did not identify diabetes as a significant risk factor for urinary incontinence (Melville et al. 2005; Song et al. 2005; Zhu et al. 2008). Diabetes mellitus has a remarkable role on urinary incontinence, as a result of glycosuria, overactivity of the detrusor muscle, recurrent urinary infections, and diabetic cystopathy (Basak et al. 2013). It was stated that hyperglycemia might cause incontinence if it increases urine volume and damages the nerve conduction of the bladder (Brown et al. 1996).

The present study revealed no significant correlation between the ages at the first and last childbirth and UI. Similar to results of the present study, Erata et al. (2002) reported that there was a negative correlation between the age at the first childbirth and UI and no correlation between the age at the last childbirth and UI. Persson et al. (2000) indicated that there was no correlation between the age at the last childbirth and UI but there was a positive correlation between the age at the first childbirth and stress incontinence. This result was interpreted as the fact that the pelvic floor muscles of young nulliparous women were more sensitive and could be affected more (Persson et al. 2000).

Masue et al. (2010) reported that women aged over 28 years at their first childbirth had 1.9 increased odds of SUI compared to women aged 25 years or younger at their first childbirth. Possible reasons for this association are that increased maternal age is a risk factor for intrapartum pelvic floor trauma and tissue recovery of the pelvic floor may slow with age; however, there is no scientific evidence to support this view (Masue et al. 2010).
The present study and other studies could not reveal any correlation between UI and smoking habits (Erata et al. 2002; Højberg et al. 1999). Sampselle et al. (2002) conducted a case-control study on 606 women and found that the risk of the urinary incontinence among smoking women was 2.5 times higher. In other studies, it was showed that smoking and being in the postpartum 12th month were risk factors for urinary incontinence (Burgio et al. 2003; Miller et al. 2003). Regarding the correlation smoking and leakage of urine, there are rational explanations concerning sphincteric, neurological and anatomic mechanisms. The adverse effect of smoking depends on estrogen levels, deterioration of collagen synthesis in the blood vessels, and severe cough. For instance, it was stated that smoking inhibited directly the collagen synthesis. The role of smoking on anti-estrogenic effect might depend on its negative effect on collagen quality and its stimulating effect on smooth muscle tonus due to the change of the activity of the alpha-adrenergic receptors (Tampakoudis et al. 1995).

\section{Conclusion}

Although urinary incontinence is a treatable condition, numerous women experience psychological, social, and physical problems due to this disorder. In this study, it was determined that $37 \%$ of the women had UI and the rate of visiting a physician for this complaint was low. This result might be interpreted as an indicator that the women did not consider urinary incontinence as a serious health problem. Unfortunately, common misunderstandings about UI are continuing and therefore, treatment of UI in these women is delayed. Preventing of making UI tabooed, the perception concerning no need for embarrassment, and its treatment with simple methods like pelvic floor exercises and providing proper incentives for the treatment of the incontinence would be very useful for the development of the healthcare-seeking behavior. It is required for future studies to focus on indepth research in order to understand the reasons for the avoidance of seeking healthcare service.

It was found that based on the correlation of UI with medical and obstetric characteristics and the logistic regression analysis of the risk factors; number of children, duration of delivery lasting longer than $24 \mathrm{~h}$, and urogenital infections were significantly correlated with UI, but not the age at first and last childbirth, presence of episiotomy, childbirth with a birth weight over $4 \mathrm{~kg}$, and smoking. In order to prevent UI affecting negatively the health and the quality of life of women, high multiparity, urinary infection, and diabetes should be addressed. Nurses and midwives have an important role in the education of women regarding prevention of the risk factors like obesity, constipation, urinary infections, and Kegel 
exercises. In conclusion, in order to eliminate the negative effects of UI on quality of life, it is essential to focus on prevention of UI's risk factors.

\section{Abbreviations \\ UI: urinanry incontinence; POP: pelvic organ prolapse.}

\section{Acknowledgements}

Meral Kılıç would like to thank all of those who participated in this study.

\section{Competing interests}

Meral Kılıç have full control of all primary data and agree to allow the journal to review the data if requested.

Received: 31 January 2016 Accepted: 29 July 2016

Published online: 11 August 2016

\section{References}

Abrams P, Andersson KE, Birder L, Brubaker L, Cardozo L, Chapple C, Drake M (2010) Fourth international consultation on incontinence recommendations of the international scientific committee: evaluation and treatment of urinary incontinence, pelvic organ prolapse, and fecal incontinence. Neurourol Urodyn 29(1):213-240. doi:10.1002/nau.20870

Al-Badr A, Brasha H, Al-Raddadi R, Noorwali F, Ross S (2012) Prevalence of urinary incontinence among Saudi women. Int J Gynecol Obstet 117(2):160-163. doi:10.1016/j.jijo.2011.12.014

Altaweel W, Alharbi M (2012) Urinary incontinence: prevalence, risk factors, and impact on health related quality of life in Saudi women. Neurourol Urodyn 31(5):642-645. doi:10.1002/nau.22201

AnChiu C, Xian W, Moss CF (2008) Flying in silence: echolocating bats cease vocalizing to avoid sonar jamming. Proc Natl Acad Sci USA 105(35):13116-13121. doi:10.1073/pnas.0804408105

Ateşkan Ü, Mas MR, Doruk H, Kutlu M (2000) Yaşlı Türk popülasyonunda ürine inkontinans: Görülme sıklığı, muhtemel klinik tipleri ve birey açısından öneminin değerlendirilmesi (Urınary incontinence among the enderly people of Turkey: prevalance, clinical types and health-care seeking). Geriatri 3(2):45-50

Basak T, Kok G, Guvenc G (2013) Prevalence, risk factors and quality of life in Turkish women with urinary incontinence: a synthesis of the literature. Int Nurs Rev 60(4):448-460. doi:10.1111/inr.12048

Bates P, Bradley W, Glen E, Griffiths D, Melchior H, Rowan D, Hald T (1979) The standardization of terminology of lower urinary tract function. J Urol 121(5):551-554

Berglund AL, Eisemann M, Lalos O (1994) Personality characteristics of a stress incontinent women: a pilot study. J Psychosom Obstet Gynecol 15(3):165-170. doi:10.3109/01674829409025642

Bilgili N, Belgin A, Emel E, Sultan A (2008) Kadınlarda üriner inkontinans sıklığ ve etkileyen risk faktörleri (Incidence of the urinary incontinence and affecting risk factors in women) Turkiye Klinikleri. J Med Sci 28(4):487-493

Brown JS, Seeley DG, Fong J, Black DM, Ensrud KE, Grady D, Group S (1996) Urinary incontinence in older women: who is at risk? Obstet Gynecol 87(5):715-721. doi:10.1016/0029-7844(96)00013-0

Burgio KL, Zyczynski H, Locher JL, Richter HE, Redden DT, Wright KC (2003) Urinary incontinence in the 12-month postpartum period. Obstet Gynecol 102(6):1291-1298. doi:10.1016/j.obstetgynecol.2003.09.013

Chang SR, Chen KH, Lin HH, Chao YM, Lai YH (2011) Comparison of the effects of episiotomy and no episiotomy on pain, urinary incontinence, and sexual function 3 months postpartum: a prospective follow-up study. Int J Nurs Stud 48(4):409-418. doi:10.1016/j.jinurstu.2010.07.017

Chiarelli P, Brown W, McElduff P (1999) Leaking urine: prevalence and associated factors in Australian women. Neurourol Urodyn 18(6):567-577

Çiftçi Ö, Günay O (2011) Prevalence of urinary incontinence and affecting factors among the women attending gynaecology clinics of Kayseri Education and Research Hospital. Erciyes Med J 33(4):301-308
Connolly TJ, Litman HJ, Tennstedt SL, Link CL, McKinlay JB (2007) The effect of mode of delivery, parity, and birth weight on risk of urinary incontinence. Int Urogynecol J 18(9):1033-1042. doi:10.1007/s00192-006-0286-4

Doughty DB (2012) Urinary and fecal incontinence; current management concepts, 3rd edn. Mosby Elsevier, Atlanta

El-Azab AS, Mohamed EM, Sabra HI (2007) The prevalence and risk factors of urinary incontinence and its influence on the quality of life among Egyptian women. Neurourol Urodyn 26(6):783-788. doi:10.1002/nau.20412

Erata Y, Kilic B, Güçlü S, Saygili U, Uslu T (2002) Risk factors for pelvic surgery. Arch Gynecol Obstet 267(1):14-18. doi:10.1007/s00404-001-0256-5

Ghafouri A, Alnaimi AR, Alhothi HM, Alroubi I, Alrayashi M, Molhim NA, Shokeir AA (2014) Urinary incontinence in Qatar: a study of the prevalence, risk factors and impact on quality of life. Arab J Urol 12(4):269-274. doi:10.1016/j.aju.2014.08.002

Hägglund D, Olsson H, Leppert J (1999) Urinary incontinence: an unexpected large problem among young females. Results from a population-based study. Fam Pract 16(5):506-509. doi:10.1093/fampra/16.5.506

Hägglund D, Walker-Engström ML, Larsson G, Leppert J (2001) Quality of life and seeking help in women with urinary incontinence. Acta Obstet Gynecol Scand 80(11):1051-1055. doi:10.1034/j.1600-0412.2001.801117x

Hannestad YS, Rortveit G, Sandvik H, Hunskaar S (2000) A community-based epidemiological survey of female urinary incontinence: the Norwegian EPINCONT Study. J Clin Epidemiol 53(11):1150-1157. doi:10.1016/ S0895-4356(00)00232-8

Hartmann K, Viswanathan M, Palmieri R, Gartlehner G, Thorp J, Lohr KN (2005) Outcomes of routine episiotomy: a systematic review. JAMA 293(17):2141-2148. doi:10.1001/jama.293.17.2141

Højberg KE, Salvig JD, Winsløw NA, Lose G, Secher NJ (1999) Urinary incontinence: prevalence and risk factors at 16 weeks of gestation. BJOG Int J Obstet Gynaecol 106(8):842-850. doi:10.1111/j.1471-0528.1999.tb08407.x

Hunskaar S, Burgio K, Diokno A, Herzog AR, Hjälmås K, Lapitan MC (2003) Epidemiology and natural history of urinary incontinence in women. Urology 62(4):16-23. doi:10.1007/s001920070021

Işıklı B, Yenilmez A, Kalyoncu C (2011) Eskişehir Alpu ilçesi 18 yaş üstü kadınlarda üriner inkontinans risk faktörleri ve yaşam kalitesine etkisi. Bir toplum tabanlı çalışma (Risk factors of urinary incontinence in women with an age over 18 years and it's effect on the quality of life in the town Alpu, Eskişehir: a population-based study). Nobel Med 7(1):54-57

Karaçam Z, Eroğlu K (2003) Effects of episiotomy on bonding and mothers' health. J Adv Nurs 43(4):384-394. doi:10.1046/j.1365-2648.2003.02727.x

Kaşıkçı M, Kılıç D, Avşar G, Şirin M (2015) Prevalence of urinary incontinence in older Turkish women, risk factors, and effect on activities of daily living. Arch Gerontol Geriatr 61(2):217-223. doi:10.1016/j.archger.2015.06.008

Kinchen KS, Burgio K, Diokno AC, Fultz NH, Bump R, Obenchain R (2003) Factors associated with women's decisions to seek treatment for urinary incontinence. J Women's Health 12(7):687-698. doi:10.1089/154099903322404339

Kızılkaya B (2002) Kadınlarda Üriner İnkontinans ve Hemşirelik Yaklaşımı (Urinary incontinence in women and nursery approach). İstanbul Üniversitesi Yayınları, Yayın Emek Matbaacılık, İstanbul 5:51-60

Kocaöz S, Eroğlu K (2002) Kadınlarda stres üriner inkontinans yaygınlı̆̆ bunu etkileyen faktörlerin belirlenmesi (The frequency and determination of stress urinary incontinence in women). Hemşire Araştırma Derg 4:29-39

Koch LH (2006) Help-seeking behaviors of women with urinary incontinence: an integrative literature review. J Midwifery Womens Health 51(6):e39-e44

Kök G, Şenel N, Akyüz A (2006) GATA jinekoloji polikliniğine başvuran 20 yaş üstü kadınların üriner inkontinans açısından farkındalık durumlarının değerlendirilmesi (Evaluation of the awareness level of the women over 20 years of age visited gynecology outpatient clinic of GATA regarding urinary incontinence). Gülhane Tıp Derg 48(3):132-136

Masue T, Wada K, Nagata C, Deguchi T, Hayashi M, Takeda N, Yasuda K (2010) Lifestyle and health factors associated with stress urinary incontinence in Japanese women. Maturitas 66(3):305-309. doi:10.1016/j. maturitas.2010.04.002

Melville JL, Katon W, Delaney K, Newton K (2005) Urinary incontinence in US women: a population-based study. Arch Intern Med 165(5):537-542. doi:10.1001/archinte.165.5.537

Meschia M, Buonaguidi A, Pifarotti P, Somigliana E, Spennacchio M, Amicarelli F (2002) Prevalence of anal incontinence in women with 
symptoms of urinary incontinence and genital prolapse. Obstet Gynecol 100(4):719-723

Miller YD, Brown WJ, Smith N, Chiarelli P (2003) Managing urinary incontinence across the lifespan. Int J Behav Med 10(2):143-161. doi:10.1207/ S15327558IJBM1002_04

Milsom I, Ekelund P, Molander U, Arvidsson L, Areskoug B (1993) The influence of age, parity, oral contraception, hysterectomy and menopause on the prevalence of urinary incontinence in women. J Urol 149(6):1459-1462

Nakayama H, Jørgensen H, Pedersen P, Raaschou H, Olsen T (1997) Prevalence and risk factors of incontinence after stroke the Copenhagen stroke study. Stroke 28(1):58-62. doi:10.1161/01.STR.28.1.58

Norton P, Brubaker L (2006) Urinary incontinence in women. The Lancet 367(9504):57-67. doi:10.1016/S0140-6736(06)67925-7

Nygaard IE, Thompson FL, Svengalis SL, Albright JP (1994) Urinary incontinence in elite nulliparous athletes. Obstet Gynecol 84(2):183-187

Oliveira E, Zuliani L, Ishicava J, Silva SV, Albuquerque SS, Souza AMB, Barbosa CP (2010) Evaluation of factors related to the occurrence of female urinary incontinence. Rev Assoc Med Bras 56(6):688-690. doi:10.1590/ S0104-42302010000600019

Ortiz OC (2004) Stress urinary incontinence in the gynecological practice. Int J Gynecol Obstet 86:6-16. doi:10.1016/j.ijgo.2004.05.004

Ostergard DR, Bent AE (1996) Urogynecology and urodynamics: theory and practice. Lippincott Williams \& Wilkins, Philadelphia, pp 569-579

Persson J, Wølner-Hanssen P, Rydhstroem H (2000) Obstetric risk factors for stress urinary incontinence: a population-based study. Obstet Gynecol 96(3):440-445

Rizk DE, Hassan MY, Shaheen H, Cherian JV, Micallef R, Dunn E (2001) The prevalence and determinants of health care-seeking behavior for fecal incontinence in multiparous United Arab Emirates females. Dis Colon Rectum 44(12):1850-1856. doi:10.1007/BF02234467

Rortveit G, Daltveit AK, Hannestad YS, Hunskaar S (2003) Vaginal delivery parameters and urinary incontinence: the Norwegian EPINCONT study. Am J Obstet Gynecol 189(5):1268-1274. doi:10.1067/ S0002-9378(03)00588-X

Sampselle CM, Harlow SD, Skurnick J, Brubaker L, Bondarenko I (2002) Urinary incontinence predictors and life impact in ethnically diverse perimenopausal women. Obstet Gynecol 100(6):1230-1238. doi:10.1097/ AOG.00000000000000808

Sartore A, De Seta F, Maso G, Pregazzi R, Grimaldi E, Guaschino S (2004) The effects of mediolateral episiotomy on pelvic floor function after vaginal delivery. Obstet Gynecol 103(4):669-673. doi:10.1097/01. AOG.0000119223.04441.c9

Shakhatreh F (2005) Epidemiology of urinary incontinence in Jordanian women. Saudi Med J 26(5):830-835

Şirin A, Kavlak O (2008) Kadın Sağ|ı̆ıı, (Women's health). Bedray Basın Yayıncılık Ltd. Şti., İstanbul, p 181

Song YF, Zhang WJ, Song J, Xu B (2005) Prevalence and risk factors of urinary incontinence in Fuzhou Chinese women. Chin Med J 118(11):887-892

Tampakoudis P, Tantanassis T, Grimbizis G, Papaletsos M, Mantalenakis S (1995) Cigarette smoking and urinary incontinence in women a new calculative method of estimating the exposure to smoke. Eur J Obstet Gynecol Reprod Biol 63(1):27-30. doi:10.1016/0301-2115(95)02212-P

Taşkın L (2007) Doğum ve kadın sağ| $\mid$ ğı hemşireliği (Nursery for Childbirth and Women's Health). Sistem Ofset Matbaacilık, Ankara, 2002

Thom DH, Brown JS (1998) Reproductive and hormonal risk factors for urinary incontinence in later life: a review of the clinical and epidemiologic literature. J Am Geriatr Soc 46(11):1411-1417. doi:10.1111/j.1532-5415.1998. tb06009.x

Valvanne J, Juva K, Erkinjuntti T, Tilvis R (1996) Major depression in the elderly: a population study in Helsinki. Int Psychogeriatr 8(03):437-443. doi:10.1017/S1041610296002797

Viktrup L, Lose G, Rolff M, Barfoed K (1992) The symptom of stress incontinence caused by pregnancy or delivery in primiparas. Obstet Gyneco 79(6):945-949

Williams K (2004) Stress urinary incontinence: treatment and support. Nurs Stand 18(31):45. doi:10.7748/ns2004.04.18.31.45.c3590

Williams K, Perry S, Brittain K, Team LS (2001) Patient goal setting in continence care: a useful assessment tool? Clin Eff Nurs 5(1):10-17. doi:10.1054/ cein.2000.0159

Wu C, Wang K, Sun T, Xu D, Palmer MH (2015) Predicting help-seeking intention of women with urinary incontinence in Jinan, China: a theory of planned behaviour model. J Clin Nurs 24(3-4):457-464. doi:10.1111/ jocn.12623

Yu HJ, Wong WY, Chen J, Chie WC (2003) Quality of life impact and treatment seeking of Chinese women with urinary incontinence. Qual Life Res 12(3):327-333. doi:10.1023/A:1023250632395

Zhu L, Lang J, Wang H, Han S, Huang J (2008) The prevalence of and potential risk factors for female urinary incontinence in Beijing, China. Menopause 15(3):566-569. doi:10.1097/gme.0b013e31816054ac

\section{Submit your manuscript to a SpringerOpen ${ }^{\circ}$ journal and benefit from:}

- Convenient online submission

- Rigorous peer review

- Immediate publication on acceptance

- Open access: articles freely available online

- High visibility within the field

- Retaining the copyright to your article

Submit your next manuscript at $\boldsymbol{\nabla}$ springeropen.com 